\title{
Decatropis bicolor (Zucc.) Radlk essential oil induces apoptosis of the MDA-MB-231 breast cancer cell line
}

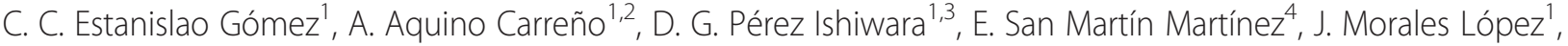 \\ N. Pérez Hernández ${ }^{1}$ and M. C. Gómez García $a^{*}$
}

\begin{abstract}
Background: Decatropis bicolor (Zucc.)Radlk is a plant that has been traditionally used for the treatment of breast cancer in some communities of Mexico. So, the aim of this study was to determine the cytotoxic and apoptotic effect of the essential oil of Decatropis bicolor against breast cancer cell line, MDA-MB-231.

Methods: The essential oil obtained from hydrodestillation of leaves of Decatropis bicolor was studied for its biological activity against breast cancer cells MDA-MB-231 by MTT assay, Hematoxylin-eosin stain, Annexin V-FITC, TUNEL and western blot assays and for its chemical composition by GC-MS.

Results: The results showed a relevant cytotoxic effect of the essential oil towards MDA-MB-231 cells in a dose- and time- dependent manner, with an $I_{50}$ of $53.81 \pm 1.691 \mu \mathrm{g} / \mathrm{ml}$ but not in the epithelial mammary cell line MCF10A $(207.51 \pm 3.26 \mu \mathrm{g} / \mathrm{ml})$. Morphological examination displayed apoptotic characteristics in the treated cells like cell size reduction, membrane blebbing and apoptotic bodies. In addition, the apoptotic rate significantly increased as well as DNA fragmentation and western blot analysis revealed that the essential oil induced apoptosis in the MDA-MB-231 cells via intrinsic pathways due to the activation of Bax, caspases 9 and 3. Phytochemical analysis of the Decatropis bicolor essential oil showed the presence of twenty-three compounds. Major components of the oil were 1,5-cyclooctadiene,3-(methyl-2)propenyl (18.38\%), 3 -terpineol (8.16\%) and 1-(3-methyl-cyclopent-2-enyl)-cyclohexene (6.12\%).

Conclusions: This study suggests that essential oil of Decatropis bicolor has a potential cytotoxic and antitumoral effect against breast cancer cells, with the presence of potential bioactive compounds. Our results contribute to the validation of the anticancer activity of the plant in Mexican traditional medicine.
\end{abstract}

Keywords: Essential oil, Breast cancer, Cytotoxic

\section{Background}

Cancer is a leading cause of mortality worldwide, and according to the American Cancer Society, deaths from cancer constitute $2-3 \%$ of the annual deaths recorded worldwide. An estimated 14.1 million new cancer cases occurred in 2012, and breast cancer was the most common cancer diagnosed in women, representing $25.2 \%$ of all new cases in women [1].

\footnotetext{
*Correspondence: cgomezg@ipn.mx; consuelogg22@yahoo.com.mx

'Programa de Doctorado en Biotecnología, Escuela Nacional de Medicina y Homeopatía, Instituto Politécnico Nacional, Guillermo Massieu Helguera No. 239, Fracc. La Escalera, Ticomán, Delg. Gustavo A. Madero, Mexico C.P. 07320, D. F., Mexico

Full list of author information is available at the end of the article
}

Chemotherapy is a major treatment modality that is used for the control of breast cancer; however, the drugs used exhibit severe toxicity to normal tissues, causing serious side effects [2]. Therefore, many cancer patients seek alternative and/or complementary methods of treatment, such as medicinal plants [3], and there is an urgent need for novel treatment options with improved properties.

Plants are a potential source for drug discovery and the development of cancer chemoprevention. In fact, at least $60 \%$ of the currently used anticancer agents, such as paclitaxel or the vinca alkaloids, vincristine and vinblastine, are derived from natural sources [4]. Several 
reports indicate that the anticancer activity of medicinal plants is due to the presence of different metabolites. Medicinal plants possess no toxicity compared to modern (allopathic) drugs [4, 5]. The study of new natural products with anticancer activity is important to synthesize new chemical derivatives based on bioactivity and the mechanism of action [5]. Additionally, the essential oils obtained from natural sources have become increasingly popular as naturally occurring bioactive agents [6]. Essential oils (EOs) are volatile complex compounds characterized by a strong odor that are formed by aromatic plants as secondary metabolites. They have been widely used for bactericidal, insecticidal, fungicidal, antioxidant, anticancer, cardiovascular, cosmetic and food applications $[7,8]$. EOs obtained from medicinal plants have biological effects via the induction of apoptosis in various cancer cell lines and are promising for the development of novel anticancer agents.

Rutaceae is a plant family which comprises about 161 genera and 1813 species distributed worldwide [9]. Some plants of this family have been widely used in traditional medicine and in the cosmetic, food and pharmaceutical industries, where both, the extracts and the EOs have been proven [10-12]. In particularly, Mexico has a traditional of using medicinal plants from Rutaceae family such as Decatropis bicolor (Zucc.)Radlk. This plant is commonly known as arantho, is a 2-3-m tall shrub with small white flowers that is distributed from Mexico to Centroamerica. Several studies demonstrated antifungal [13] and antiinflammatory activities of different extracts of this plant [14]. The aerial parts of $D$. bicolor are traditionally used for ailments, such as backache, headache, flu, some injuries, and cancer. In communities such as El Cardonal, in Hidalgo State, Mexico, the leaves of $D$. bicolor are used to prepare infusions with approximately $5 \mathrm{~g}$ of aerial parts per $1 \mathrm{lt}$ of water, boiled for $15 \mathrm{~min}$ and drunk as daily water for the treatment of breast cancer [15-18]; therefore, evaluating the effects of the extracts and the EO of this plant is important to determine its antitumoral activity. Moreover, the plant is used to treat certain inflammatory and oxidative diseases and may have anticancer effects because there is a relationship between the production of reactive oxygen species and the origin of oxidation and inflammation that can lead to cancer.

The objective of the present study was to assess the cytotoxic activity of different plant extracts and the EO of arantho in the metastatic breast cancer cell line, MDAMB-231, to determine their specific anticancer activities using various assays.

\section{Methods}

\section{Plant material and extraction}

The plant was collected in El Cardonal, Hidalgo State, Mexico on April, 2013. Taxonomic identification of the plant was performed by a botanist at the herbarium Izta of the FES-Iztacala, UNAM (Universidad Nacional Autonoma de Mexico), and a voucher specimen (1917) was deposited in the herbarium.

To prepare the different extracts, maceration technique was used, the leaves were washed and dried at room temperature and then ground into a powder. Four different solvents, water, ethanol, acetone, and hexane, were used. For each extraction, $10 \mathrm{~g}$ of the plant was dissolved in $100 \mathrm{~mL}$ of the different solvents and left it to macerate in the dark for $24 \mathrm{~h}$. Then, each extract was filtered and either lyophilized (water) or vacuum-evaporated (ethanol, acetone, hexane). For EO isolation, fresh leaves $(1 \mathrm{~kg})$ were chopped and hydrodistilled separately for $4 \mathrm{~h}$ using a low pressure and low temperature method reported previously [19]. Leaves were ground with water in a blender, deposited into a flask and then brought to a boil. The vapors were condensed on a cold surface using a condenser. The EO was separated based on the difference in density and immiscibility, which was then collected and stored at $4{ }^{\circ} \mathrm{C}$ until use. Each extract and the EO were dissolved in $0.1 \%$ dimethylsulfoxide (DMSO) and then diluted with DMEM to the desired final concentration.

\section{EO analysis by the gas chromatography-mass spectrometry (GC-MS) method}

EO was diluted in dichloromethane at a ratio of 2:48. A volume of $1 \mu \mathrm{L}$ was manually injected in the split mode into a GC-MS (Perkin Elmer, Turbo Mass Autosystem XL, (Norwalk, CT)) equipped with an HP-FFAP capillary column $19091 \mathrm{~F}-413$ (30 m*0.32 id*0.25 $\mu \mathrm{m}$ film thickness). The injection port was at $180^{\circ} \mathrm{C}$, and the oven temperature was set at $50{ }^{\circ} \mathrm{C}$, increased to $130{ }^{\circ} \mathrm{C}$ at a rate of $6{ }^{\circ} \mathrm{C} \mathrm{min}-1$ and maintained for $3 \mathrm{~min}$. A second set was used at $200{ }^{\circ} \mathrm{C}$, with an increase of $8{ }^{\circ} \mathrm{C} \mathrm{min}{ }^{-1}$ over $8 \mathrm{~min}$. The carrier gas was high-purity helium at 8 psi. The selective mass detector was a quadrupole Perkin Elmer TurboMass with an electronic impact ionization system at $70 \mathrm{eV}$ and at $215^{\circ} \mathrm{C}$. The results are presented as the relative area \% of the total-ion chromatogram, and the percentage composition was calculated by the normalization method of peak areas from the $\mathrm{GC}$ as the average value of three injections of oil without correction factors. The compounds were identified by comparing the spectra of the compounds from the EO with the spectral database (NIST MS Search 1.7). The linear retention indices (RI) of the volatile compounds were calculated with $n$-alkanes series $\left(\mathrm{C}_{10}-\mathrm{C}_{26}\right)$.

\section{Cell culture}

The breast adenocarcinoma MDA-MB-231 and the epithelial mammary cell line MCF10-A were purchased from American Type Culture Collection (ATCC, Rockville). MDA-MB-231 cell line was maintained in DMEM (Dulbecco's Modified Eagle Medium, Gibco) supplemented with 
$5 \%$ fetal bovine serum (Invitrogen). MCF10-A cell line was maintained in DMEM/F12 medium supplemented with $10 \%$ serum fetal bovine, hydrocortisone $(1 \mathrm{mg} / \mathrm{mL})$, EGF $(100 \mathrm{mg} / \mathrm{mL})$ and insulin $(100 \mathrm{mg} / \mathrm{mL})$. The cells were grown at $37{ }^{\circ} \mathrm{C}$ in a humidified atmosphere of $5 \% \mathrm{CO}_{2}$.

\section{MTT viability assay}

Cell viability was evaluated by a MTT (3-(4, 5- dimethyl thiazol-2-yl)-2, 5-diphenyl tetrazolium bromide) assay using a modified method of Mosmann [20]. Briefly, 7000 cells were seeded in 96 microplates and incubated for $24 \mathrm{~h}$ at $37{ }^{\circ} \mathrm{C}$ in $5 \% \mathrm{CO}_{2}$. Next, the medium was removed and replaced with fresh medium with or without treatment. The cells were treated using different concentrations of each extract $(50-400 \mu \mathrm{g} / \mathrm{mL})$ and the EO $(20-100 \mu \mathrm{g} / \mathrm{mL})$ and were incubated for 24,48 and $72 \mathrm{~h}$. Paclitaxel $(0.25 \mu \mathrm{g} /$ $\mathrm{mL}$ ) was used as the positive control, and cells with medium alone and $0.1 \%$ DMSO were used as negative controls. After incubation, $20 \mu \mathrm{l}$ of MTT solution $(5 \mathrm{mg} /$ $\mathrm{mL}$ ) was added to each well and incubated for $3 \mathrm{~h}$. Then, the medium containing MTT was replaced with $100 \mu \mathrm{l}$ of DMSO and the absorbance was measured at $570 \mathrm{~nm}$ with an ELISA reader (Labsystem Multiskan Ms). Each experiment was performed in triplicate and repeated three times. Cell viability was expressed as the percentage of control cells. The $\mathrm{IC}_{50}$ (50\% inhibitory concentration) was calculated using GraphPad Prism 5.0 software.

\section{Cell morphology analysis}

EO exhibited the greatest cytotoxic effect on MDA-MB231 breast cancer cells; therefore, the following assays were performed to analyze the apoptotic effect of the EO on this cell line. To analyze the morphological changes in the cells caused by EO, the cells were stained with hematoxylin and eosin (H\&E) technique. MDA-MB-231 cells $\left(1 \times 10^{4}\right)$ were seeded on a 6 -well plate for $24 \mathrm{~h}$. After incubation and attachment, the cells were treated with EO using the $\mathrm{IC}_{50}$ concentration $(53.81 \pm 1.691 \mu \mathrm{g} / \mathrm{mL})$ for 3 , 6, 12 and $24 \mathrm{~h}$. Then, the cells were washed with PBS $\mathrm{pH} 7.4$ and fixed in a $4 \%$ paraformaldehyde solution for $30 \mathrm{~min}$. The cells were washed again and stained with H\&E methods and observed under a light microscope (Nikon Eclipse TE300).

\section{Annexin V-FITC binding assay}

Apoptosis was determined using the Annexin V-FITC Apoptosis Detection kit (Biovision) according to the manufacturer's instructions. Briefly, MDA-MB-231 cells were cultured at a density of $5 \times 10^{5}$ and allowed to attach overnight, followed by treatment with the $\mathrm{EO}\left(\mathrm{IC}_{50}\right.$ value) or the controls for $0.5,1.5,3,6,12$ and $24 \mathrm{~h}$. The cells were then harvested by trypsinization, centrifuged and washed with PBS and incubated in binding buffer with $5 \mu \mathrm{l}$ of annexin- $\mathrm{V}$ and $5 \mu \mathrm{l}$ of propidium iodide for $5 \mathrm{~min}$ in the dark at room temperature.

Analysis was performed by flow cytometry (FACScan, Becton Dickinson Cytometer). A minimum of 10,000 events was collected for analysis.

\section{Terminal deoxynucleotidyl transferase-mediated dUTP nick end labeling (TUNEL)}

DNA fragmentation, a characteristic of apoptosis, was assessed using an In Situ Cell Death Detection Kit AP (Roche) following the manufacturer's instructions. Briefly, breast cancer cells $\left(5 \times 10^{4}\right)$ were cultured on 6-well plates over coverslips and incubated for $24 \mathrm{~h}$. The cells were then treated with $\mathrm{EO}\left(\mathrm{IC}_{50}\right.$ value) for different times (1.5, $3,6,12$ and $24 \mathrm{~h}$ ). Also cells were treated with media alone, DNAse (3000 U/mL) or paclitaxel $(0.25 \mu \mathrm{g} / \mathrm{mL})$ for $24 \mathrm{~h}$. Next, the cells were washed with PBS and fixed in paraformaldehyde solution. The cells were incubated in a permeabilization solution $(0.1 \%$ Triton X-100 in $0.1 \%$ sodium citrate) for $1 \mathrm{~h}$ at $4{ }^{\circ} \mathrm{C}$ and then, the cells were treated with solution $\mathrm{A}$ and $\mathrm{B}$ for $1 \mathrm{~h}$ in the dark at $37^{\circ} \mathrm{C}$. Analysis was performed by fluorescence microscopy (Nikon diaphot 200) with a laser scanning confocal imaging system (MCRR 1024).

\section{Western blotting analysis}

The analysis of protein expression involved in the two main pathways of apoptosis was performed by western blot. MDA-MB-231 breast cancer cells were seeded ( $5 \mathrm{x}$ $10^{5}$ ) for $24 \mathrm{~h}$, and the cells were then treated with EO (IC 50 value) or controls for $0.5,1.5,3,6,12$ and $24 \mathrm{~h}$. The cells were harvested by trypsinization and washed with PBS, and the pellet was resuspended in $20 \mu \mathrm{l}$ of a protease inhibitor cocktail solution and $100 \mu \mathrm{l}$ of cold lysis buffer $(50 \mathrm{mM}$ Tris- $\mathrm{HCl}, 150 \mathrm{mM} \mathrm{NaCl}, 0.1 \%$ SDS, 1 \% NP-40, 1 mmol phenylmethylsulfonyl fluoride, $100 \mu \mathrm{M}$ leupeptin, and $2 \mu \mathrm{g} / \mathrm{L}$ aprotinin). The protein lysates were centrifuged at $10,000 \mathrm{rpm}$ for $10 \mathrm{~min}$ at $4{ }^{\circ} \mathrm{C}$. The protein concentration was determined by Bradford assay. Protein extracts were reconstituted in sample buffer and the mixture was boiled for $5 \mathrm{~min}$. Equal amounts $(30 \mu \mathrm{g})$ of the denatured proteins were loaded into each lane and separated on a $15 \%$ SDS polyacrylamide gel, followed by the transfer of the proteins to a $0.45-\mu \mathrm{m}$ nitrocellulose membranes for $2 \mathrm{~h}$. The membranes were blocked with $5 \%$ non-fat dry milk and then incubated with primary rabbit polyclonal antibodies to procaspase-3 (1:200, Santa Cruz, CA), procaspase-8 (1:200, Santa Cruz, CA), procaspase-9 (1:200, Santa Cruz, CA), Bax (1:200, Santa Cruz, CA), Bcl-2 (1:200, Santa Cruz, CA), PCNA (1:100, Santa Cruz, CA), or $\beta$-actin (1:1000, Santa Cruz, $\mathrm{CA}$ ) as a positive control for $2 \mathrm{~h}$ at $4{ }^{\circ} \mathrm{C}$. They were then incubated with horseradish peroxidase-conjugated goat anti-rabbit or anti-mouse secondary antibody (1:2000) for 
$2 \mathrm{~h}$ before being visualized with diaminobenzidine solution. All experiments were performed in triplicate.

\section{Statistical analysis}

All data are expressed as means \pm S.E. One-way ANOVA followed by Tukey test was used to compare all groups to each other. For all tests, $p<0.05$ was considered significant.

\section{Results}

Effect of the different extracts and EO of arantho on viability The cytotoxic activities of the extracts and EO from arantho were analyzed by MTT assays performed on the MDA-MB-231 breast cancer cell line. The aqueous extract did not show any cytotoxic activity at any concentration or treatment period against these cancer cells. However, the ethanolic, acetonic and hexanic extracts showed a cytotoxic effect in a time- and concentration-dependent manner, with $\mathrm{IC}_{50}$ values of $128.20 \pm 2.035,203.2 \pm 2.3$ and $450.7 \pm 2.657 \mu \mathrm{g} / \mathrm{mL}$, respectively (Additional file 1). As shown in Fig. 1a, a better cytotoxic effect was observed when the MDA-MB-231 cells were exposed to the EO. After $24 \mathrm{~h}$ of incubation, the cell viability decreased 15 , 36,60 and $77 \%$ with $40,60,80$ and $100 \mu \mathrm{g} / \mathrm{mL}$, respectively. In addition, after $48 \mathrm{~h}$ of treatment, the cell viability decreased 35, 69, 88 and $91 \%$ using doses of 40, 60, 80 and $100 \mu \mathrm{g} / \mathrm{mL}$, respectively. A greater cytotoxic effect was observed after $72 \mathrm{~h}$ of incubation, with a reduction of cell viability of more than $85 \%$ for 60,80 and $100 \mu \mathrm{g} / \mathrm{mL}$. The cytotoxic effect of the EO was dose- and timedependent, with an $\mathrm{IC}_{50}$ of $53.81 \pm 1.691 \mu \mathrm{g} / \mathrm{mL}$. Paclitaxel $(0.25 \mu \mathrm{g} / \mathrm{mL})$ was used as a positive control and also caused a decrease in viability of 30,40 and $53 \%$ at 24,48 and $72 \mathrm{~h}$, respectively, whereas MDA-MB-231 cells without treatment maintained a viability of $100 \%$. These results demonstrate an important and significant cytotoxic effect of the arantho EO against MDA-MB-231 cells.

To analyze the specificity of the EO against breast cancer cells, an epithelial breast cell line, MCF-10A, was used. The results showed that MCF-10A cells treated with 20 to $80 \mu \mathrm{g} / \mathrm{mL}$ EO maintained cell viability similar to the negative controls $(100 \%)$ during all treatments. Higher doses $(100 \mu \mathrm{g} / \mathrm{mL})$ given to the normal epithelial cells for $72 \mathrm{~h}$ decreased the cell viability $25 \%$ (Fig. 1a). The $\mathrm{IC}_{50}$ value for normal epithelial cells was $207.51 \pm$ $3.26 \mu \mathrm{g} / \mathrm{mL}$, representing a 2.84 -fold higher concentration compared to the $\mathrm{IC}_{50}$ concentration for breast cancer cells. These results confirmed that EO was selective against breast cancer cells.

\section{Morphological changes on MDA-MB-231 cells exposed to arantho EO}

To determine whether the reduced cell viability of the cancer cells resulted from cell death induction, MDA-MB231 cells were incubated with the $\mathrm{EO}$ using the $\mathrm{IC}_{50}$ value for different times and were stained with H\&E. Non-treated cells possessed an elongated shape; a centrally located nucleus, forming a confluent colony; and were completely attached to the plate (Fig. 1b, c). By contrast, cells exposed to EO showed relevant morphological changes after $3 \mathrm{~h}$ of incubation, including cell size reduction, membrane blebbing, cell shrinkage and loss of colony formation (Fig. 1e). These changes increased with time, and after 6,12 and $24 \mathrm{~h}$ of incubation, the cells appeared to be rounded and apoptotic bodies were present (Fig. 1f-h). Similar characteristics were observed in breast cancer cells exposed to paclitaxel (Fig. 1d). These morphological characteristics suggest the induction of apoptosis by arantho EO.

\section{Apoptotic induction by the arantho EO}

To determine and quantify cell death, MDA-MB-231 cells were incubated with EO $(53.81 \mu \mathrm{g} / \mathrm{mL})$ and analyzed by Annexin V-FITC assays. Control cells without treatment showed $98 \%$ non-apoptotic live cells (Fig. 2a, h) and a very low percent (1-2 \%) of apoptosis and necrosis. By contrast, cells incubated with $0.25 \mu \mathrm{g} / \mathrm{mL}$ paclitaxel showed only $18 \%$ non-apoptotic live cells and displayed 69 and $12 \%$ apoptotic and necrotic cells, respectively (Fig. 2b, h). Cancer cells exposed to $53.81 \mu \mathrm{g} / \mathrm{mL}$ of EO showed decreased non-apoptotic live cells (from 45 to $5 \%$ after 1.5 and $24 \mathrm{~h}$, respectively) and increased apoptotic cells (from 47 to $85 \%$ after 1.5 and $24 \mathrm{~h}$, respectively) in a time-dependent manner (Fig. 2c-h). The percent of necrotic cells was similar for the different treatments. These results indicate that EO induces apoptosis rather than necrosis in MDA-MB-231 breast cancer cells, and this is consistent with the morphological changes observed by H\&E staining.

\section{Arantho EO induced DNA fragmentation in MDA-MB-231 cells}

To determine the ability of the arantho EO to trigger DNA fragmentation as a feature of apoptosis, TUNEL assays were performed. Breast cancer cells treated with EO $(53.81 \mu \mathrm{g} / \mathrm{mL})$ showed an increased in DNA fragmentation after 1.5, 3, 6, 12 and $24 \mathrm{~h}$ of incubation (Fig. 3d, e, f, g and h, respectively). As expected, cancer cells exposed to paclitaxel and DNase were also positively stained in the assay (Fig. 3b and c, respectively). As a control, cancer cells without treatment did not exhibit fluorescence staining in the nucleus (Fig. 3a). These findings indicate that arantho EO induced cell death in MDA-MB-231 cells by apoptosis rather than necrosis.

\section{Apoptotic effect of arantho EO on MDA-MB-231 cells is mediated by activation of caspase cascades}

To analyze the activation of an apoptotic pathway, western blot assays were performed to evaluate the expression of proteins, such as PCNA (proliferating cell nuclear antigen); procaspases 3, 8 and 9; Bcl-2; Bax; 

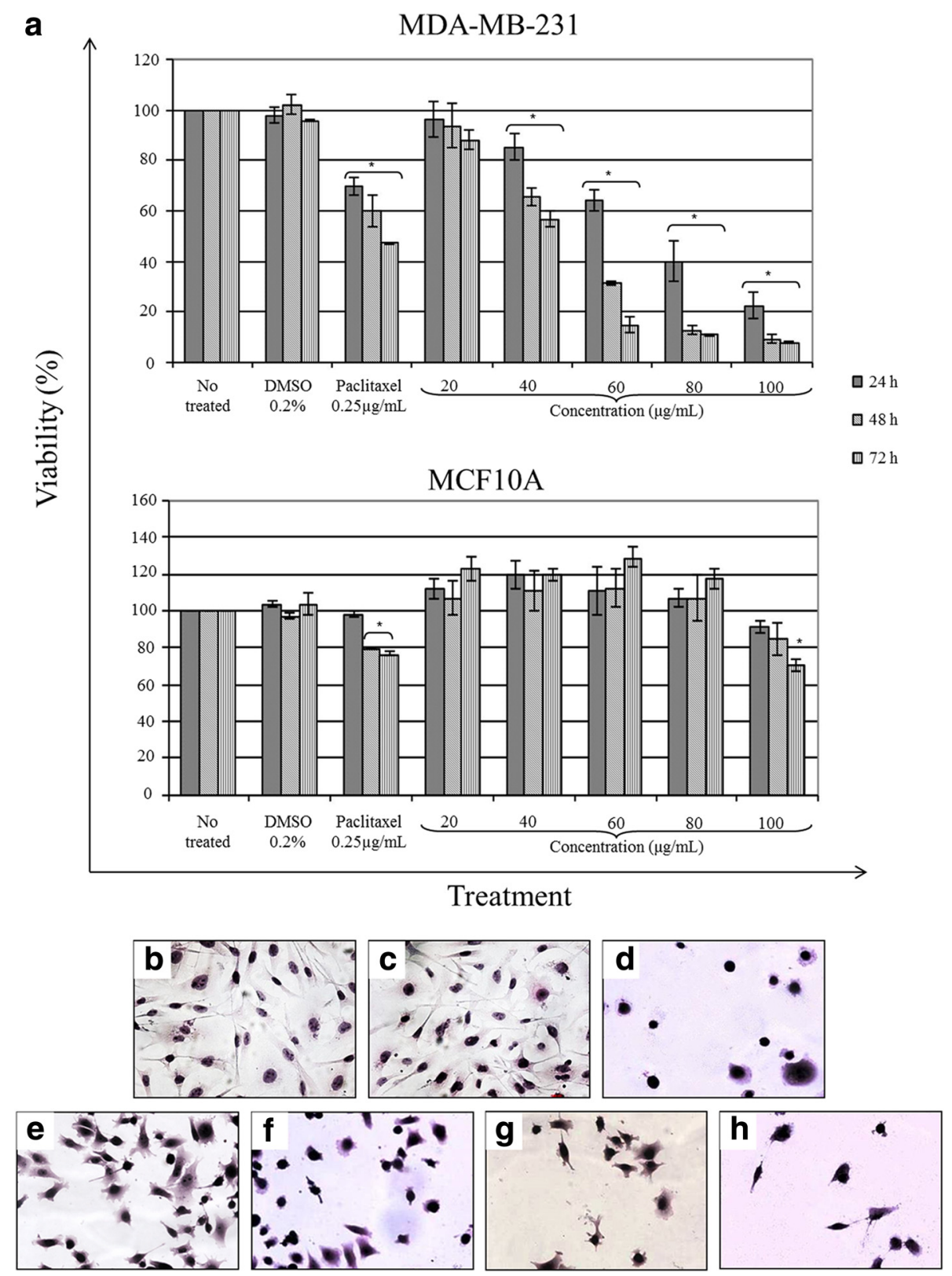

Fig. 1 Effect of arantho EO on the cellular viability and on morphological changes a Cell viability was evaluated by MTT assays using different concentrations and times of incubation (24, 48 and 72 h) of EO on MDA-MB-231, a breast carcinoma cell line, and MCF-10A, an epithelial breast cell line. b Morphological analysis of MDA-MB-231 breast cancer cells without treatment. c Cells incubated with $0.2 \%$ DMSO. d Cells exposed to paclitaxel $(0.25 \mu \mathrm{g} / \mathrm{mL})$. e-h Cells incubated with EO $(53.81 \mu \mathrm{g} / \mathrm{mL})$ for 3, 6, 12 and $24 \mathrm{~h}$, respectively. H\&E staining, 40x

and $\beta$-actin. As shown in Fig. $4 \mathrm{a}$ and $\mathrm{b}$, the expression of the PCNA protein decreased by $35 \%$ after $30 \mathrm{~min}$ of incubation with EO. In addition, at 12 and $24 \mathrm{~h}$, expression was not detected compared to the untreated cells. By contrast, the expression of procaspase- 8 ( $55 \mathrm{kDa}$ protein inactive form) was constant for the different treatments, suggesting that the extrinsic pathway was not activated. However, some changes were observed in the expression of procaspase- 9 and 3, corresponding to the inactive form of the protein for each. The expression of procaspase- 9 decreased from 30 to $90 \%$ after 1.5 to 24 h of incubation. The expression of procaspase- 3 decreased by $30 \%$ at $1.5 \mathrm{~h}$ of incubation, but at $24 \mathrm{~h}$, the protein was not detected. $\mathrm{Bcl}-2$ is an anti-apoptotic protein. It decreased after 12 and $24 \mathrm{~h}$ (18 and $40 \%$, respectively) of incubation with the breast cancer cells exposed to EO. Bax, a proapoptotic protein, increased markedly after $3 \mathrm{~h}$ of incubation (25\%). $\beta$-actin was used as the loading control and showed equal 


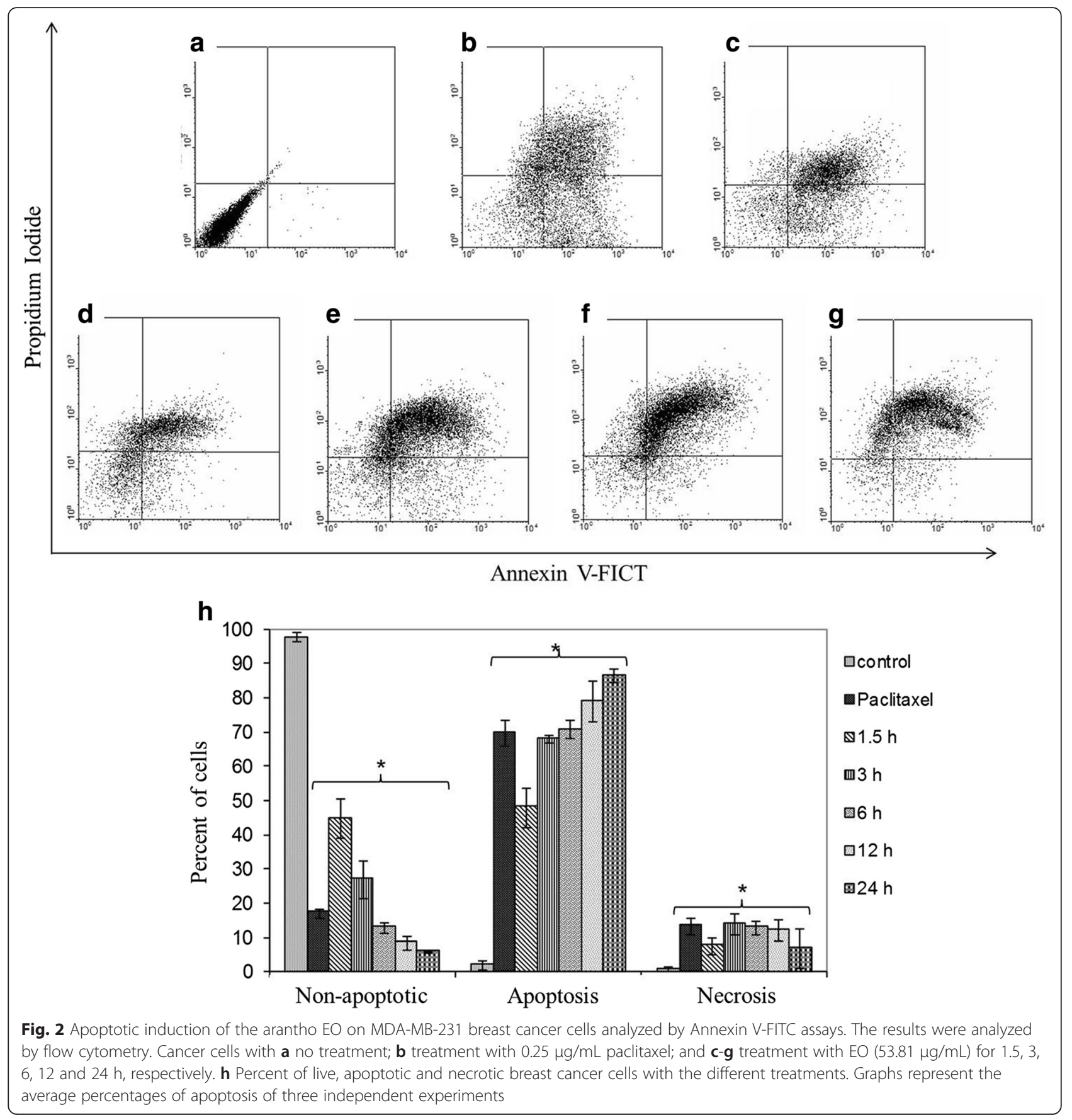

intensity bands in all samples. These results indicated that EO induced apoptotic cell death via activation of the intrinsic pathway.

\section{Chemical composition of Arantho EO}

EO was obtained using the hydrodistillation method from the fresh leaves of arantho with a yield of $23 \%$. GC-MS analyses were then used to determine the composition of the extract. Twenty-three compounds, representing $76.56 \%$ of the EO, were identified (Table 1).
These components were separated into seven classes, hydrocarbons (24.50\%), terpenes (17.85\%), alcohols (17.75\%), carboxylic acids (12.33 \%), aldehydes (3.04 \%), benzene derivatives $(1.07 \%)$ and others $(23.46 \%)$. The major components of the oil were 1,5-cyclooctadiene,3(methyl-2) propenyl (18.38\%), $\beta$-terpineol (8.16 \%), 1 (3-methyl-cyclopent-2-enyl)-cyclohexene (6.12 \%), 2heptanol acetate (5.13\%), and limonene (4.49\%). All other components were present at less than $4 \%$ abundance (Table 1). 

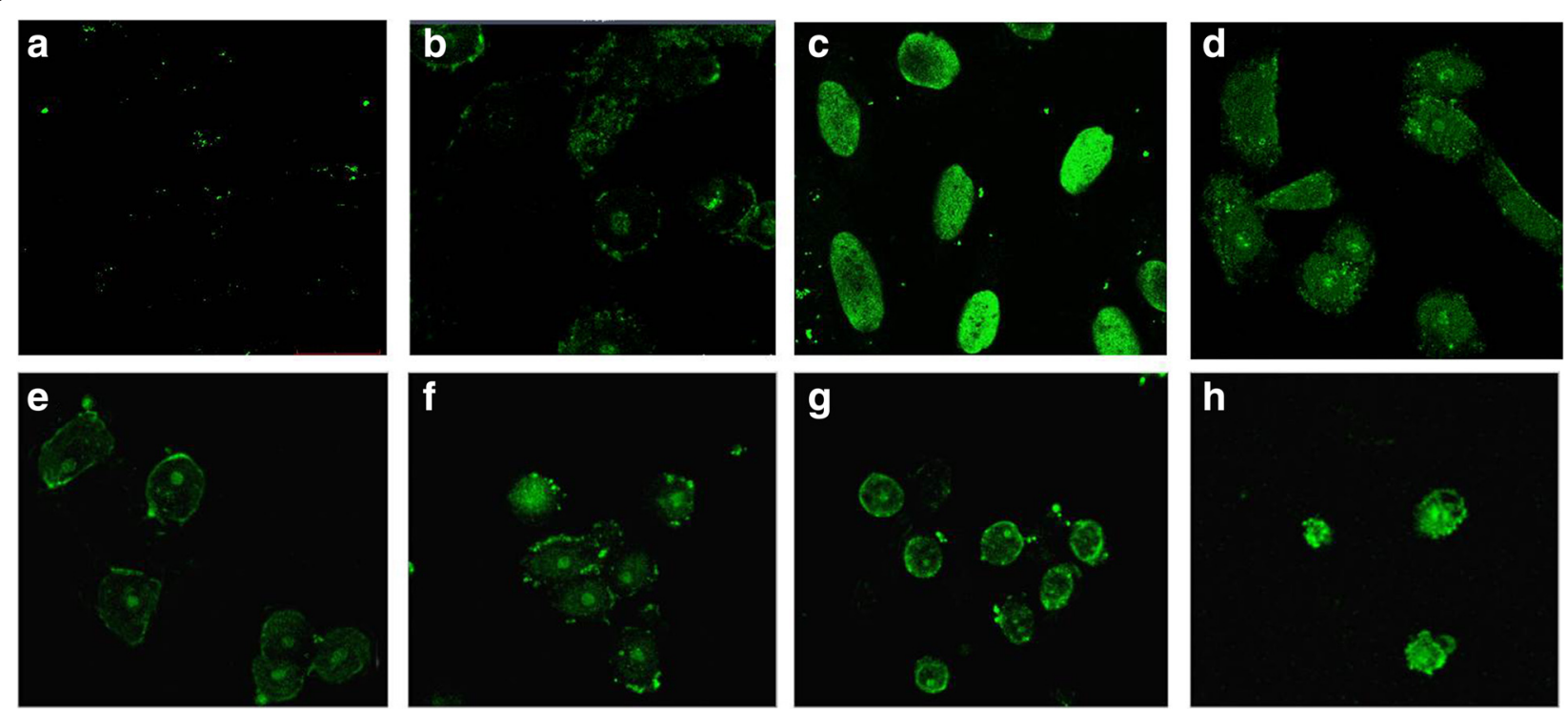

Fig. 3 Analysis of DNA fragmentation by TUNEL assay in MDA-MB-231 breast cancer cells incubated with arantho EO. a Cells without treatment. b Cells exposed to $0.25 \mu \mathrm{g} / \mathrm{mL}$ paclitaxel. c Cells treated with DNAse (3000 U/mL). d-h Cells incubated with $53.81 \mu \mathrm{gg} / \mathrm{mL}$ of EO for $1.5,3,6,12$ and $24 \mathrm{~h}$, respectively

\section{Discussion}

D. bicolor is a widely used plant by the people of several communities of central Mexico for treating breast cancer. However, little is known regarding its anti-proliferative effects in this disease. Therefore, the purpose of this study was to determine whether $D$. bicolor, commonly known as arantho, has a cytotoxic effect against breast cancer cells. In the present study, we obtained different extracts, as well as the EO of this plant, to investigate its antiproliferative effect and to characterize the type of cell death induced.

Several studies indicate that EOs possess chemopreventive potential, anti-tumoral activity and it function to induce apoptosis in different cancer cell lines [12, 21]. In particularly, plants of the Rutaceae family are characterized by the presence of odoriferous glands containing aromatic essences, and their EOs are cytotoxic in different models of cancer. These plants include Citrus $s p$. $[11,22]$ Zanthopylum fagara [23] and Ruta graveolens [24]. Several metabolites are representative of this family; however, the different phytochemical profiles are important for their biological activity.

In the present study, we showed that arantho EO, which belongs to the Rutaceae family, had time- and concentration-selective cytotoxic activity against MDAMB-231, a highly invasive estrogen receptor-negative breast cancer cell line, with an $\mathrm{IC}_{50}$ value of $53.81 \mu \mathrm{g} /$ $\mathrm{mL}$, and possessed better effects than the different extracts of $D$. bicolor, while no effect was observed using aqueous extract. The type of compounds extracted from the plant depends on the polarity, acidity and alkalinity of the solvent; which means that polar solvents such as water tends to extract polar compounds (alcohols, amines, acids, esters, sugars, glycosides), while low- or non-polar solvents such as the ethanolic, acetonic, hexanic or EO tends to extract different kinds or different quantities of non-polar compounds (fats, waxes, volatile oils) [25]. It is also possible that concentrations of active constituents in the extracts and in the EO may vary depending on the extraction conditions; the extraction time; the temperature or the extraction method. Thus, results suggest that differential content and/or concentrations specially of polar compounds, extracted with each extract influenced in the cytotoxicity observed [26].

On the other hand, the cytotoxicity was not observed in the MCF-10A epithelial mammary cell line when low concentrations of EO were used. The differential EO effect between these cell lines may be due to the specific genetic profile; to the membrane potential derived from specific ion channels; to the distinct adhesion molecules in the surface, or to other characteristics of breast cancer cells making it more sensitive to EO [27].

To determine whether the cytotoxic activity of EO was due to apoptosis, MDA-MB-231 cells were treated for 0 $24 \mathrm{~h}$ with the $\mathrm{IC}_{50}$ value of arantho and analyzed by $\mathrm{H} \& \mathrm{E}$ staining and TUNEL assays. Apoptosis is programmed cell death that maintains cellular homeostasis between cell division and cell death [28]. This physiological process induces cellular self-destruction, generating diverse morphological and biochemical features in the nucleus and cytoplasm. Apoptosis is a primary death induced by natural and certain synthetic compounds with antitumoral activities [28, 


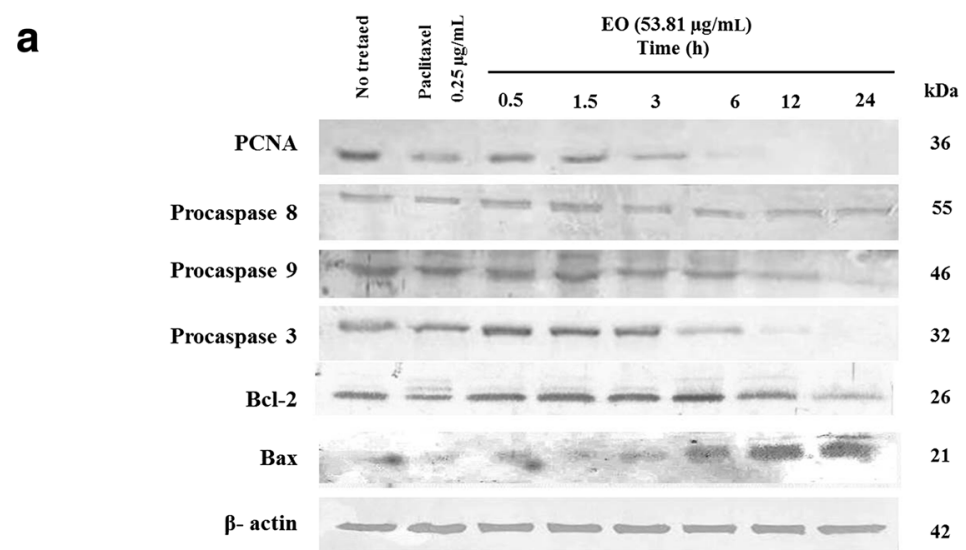

b

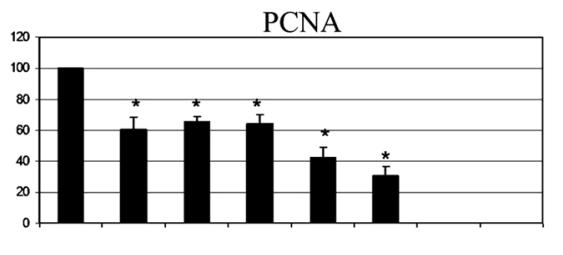

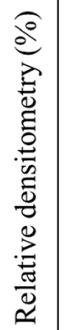

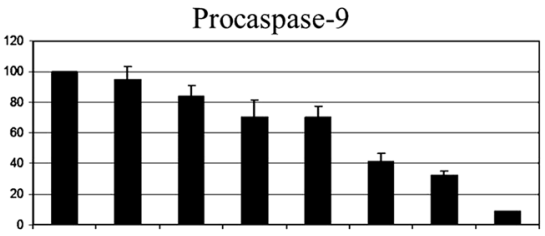

Bcl-2

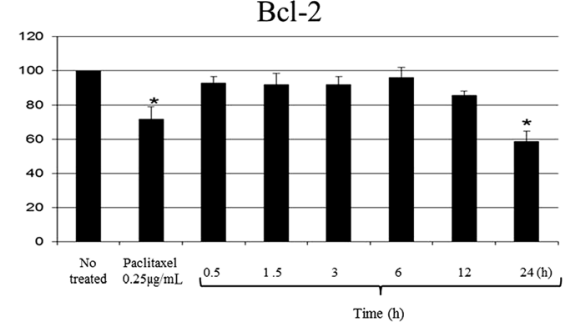

Procaspase- 8
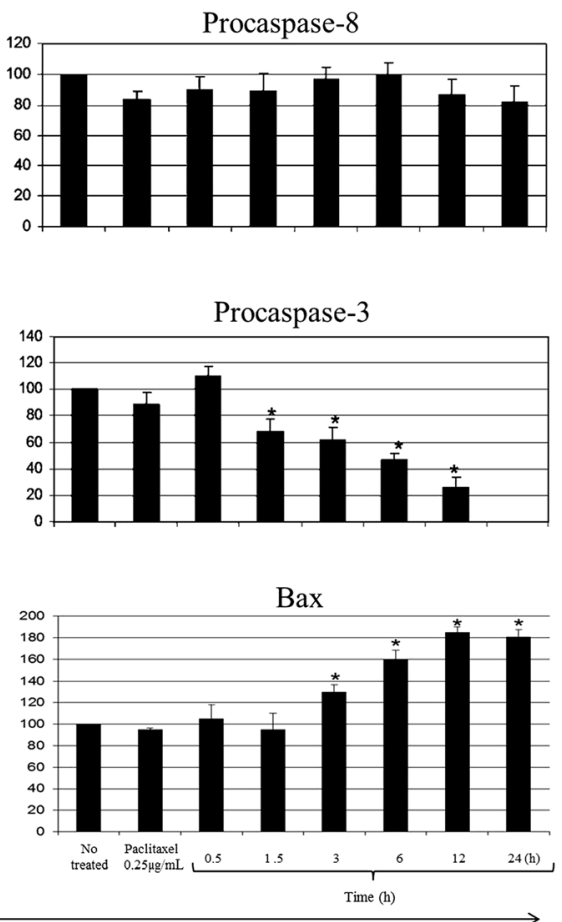

Treatment

Fig. 4 Western blot analysis of MDA-MB-231 breast cancer cells incubated with arantho $E O(53.81 \mu \mathrm{g} / \mathrm{mL})$ for $0.5,1.5,3,6,12$ and 24 h. a Analysis of the expression of PCNA; procaspase-3, 8 and 9; BCl-2; and Bax. The membranes were also detected with an antibody against $\beta$-actin as a loading control. b Relative densitometry of each protein

29]. Interestingly, arantho EO induced early ( 3 h) cell detachment, floating cell size reduction, membrane blebbing, and cell shrinkage. However, it also induced apoptotic body formation and chromatin condensation, all of which are typical features of apoptosis [29]. Moreover, DNA fragmentation was observed earlier than $3 \mathrm{~h}$ $(1.5 \mathrm{~h})$ of exposure to $\mathrm{EO}$, and increased in a timedependent manner to $24 \mathrm{~h}$, indicating that the compound or compounds induce cell damage almost immediately, rather than the metabolites. This was confirmed when we performed a quantitative analysis of apoptosis using Annexin V-FITC because the results revealed that
$47 \%$ of the MDA-MB-231 cells exposed to EO for $1.5 \mathrm{~h}$ are in apoptosis, and at $24 \mathrm{~h}$, the apoptosis rate was $85 \%$. Furthermore, necrosis was no greater than $18 \%$ in all of the tested conditions. Taken together, these findings indicate that the EO of D. bicolor induced cell death in MDA-MB-231 cells due to apoptotic rather than necrotic effects. This is consistent with the goal of potential anticancer drugs, in which a primary characteristic is to induce apoptosis. Different studies using EOs of medicinal plants have demonstrated their potential anti-cancer activity by inducing apoptosis or cell cycle arrest [30]. 
Table 1 EO composition of arantho leaves

\begin{tabular}{|c|c|c|c|c|}
\hline No & Compound & Retention time (min) & $\mathrm{KI}$ & Abundance (\%) \\
\hline 1 & a-Pinene & 1.8 & 885 & 2.60 \\
\hline 2 & Camphene & 2.06 & 1008 & 0.91 \\
\hline 3 & $\beta$-Pinene & 2.37 & 1042 & 1.18 \\
\hline 4 & $\beta$-Phellandrene & 2.5 & 1057 & 1.03 \\
\hline 5 & $\beta$-Myrcene & 2.92 & 1104 & 1.05 \\
\hline 6 & Limonene & 3.34 & 1151 & 4.49 \\
\hline 7 & 2-Hexenal & 3.63 & 1183 & 3.04 \\
\hline 8 & 3-Carene & 3.97 & 1211 & 0.94 \\
\hline 9 & 2-Heptanol acetate & 4.29 & 1230 & 5.13 \\
\hline 10 & 2-Heptanol & 4.35 & 1233 & 3.20 \\
\hline 11 & Acetic acid, octyl ester & 6.3 & 1348 & 1.28 \\
\hline 12 & Eucalyptol & 6.90 & 1383 & 1.10 \\
\hline 13 & Linalool & 7.2 & 1401 & 1.53 \\
\hline 14 & 1-(3-Methyl-cyclopent-2-enyl)-cyclohexene & 7.38 & 1410 & 6.12 \\
\hline \multirow[t]{2}{*}{15} & Acetic acid,1,7.7-trime-bicyclo [2.2.1] & 7.51 & 1417 & 3.82 \\
\hline & hept-2-yl ester & & & \\
\hline 16 & Terpineol & 7.65 & 1424 & 1.04 \\
\hline 17 & Acetic acid, decyl ester & 8.36 & 1461 & 2.11 \\
\hline 18 & $\beta$-Terpineol & 8.91 & 1490 & 8.16 \\
\hline 19 & 1,5-Cyclooctadiene,3-(methyl-2)propenyl & 9.45 & 1518 & 18.38 \\
\hline 20 & Germacrene & 12.16 & 1657 & 3.07 \\
\hline 21 & Methyl salicylate & 13.5 & 1684 & 1.07 \\
\hline 22 & Elemol & 16.71 & 1870 & 1.07 \\
\hline 23 & Hedycaryol & 19.36 & 1980 & 1.05 \\
\hline
\end{tabular}

KI Kovats Retention Index

Apoptosis is activated by two different pathways, the intrinsic and extrinsic pathways. The extrinsic pathway is mediated by death receptors, whereas the intrinsic or mitochondrial pathway is triggered by the release of apoptogenic proteins, such as cytochrome $\mathrm{c}$, which activate caspase proteins that are the main effector molecules that induce this process [28]. Arantho EO activated caspases 9 and 3 at short treatment times. Caspase 3 is an executer protein that cleaves different substrates to generate DNA fragmentation and morphological changes, such as the appearance of apoptotic bodies. These characteristics were observed at different times of exposure. By contrast, caspase 8 , a protein that self-cleaves as a result of the activation of the extrinsic pathway, maintained expression when breast cancer cells were exposed to arantho EO. This result indicated that the extrinsic pathway was not activated. Additionally, the EOs of Citrus bergamia (0.005 \%) and Aniba rosaeodora $(400 \mathrm{~nL} / \mathrm{mL})$ also induce apoptosis via the activation of caspase 3 and 9 after 1 and $2 \mathrm{~h}$ of treatment for the SH-SY5Y and A431 cell lines, respectively [12]. By contrast, the Bcl-2 family is also a key regulator of apoptosis, and it includes apoptotic (Bax, Bak, and
Bid) and antiapoptotic molecules (Bcl-2 and Bcl-xl) [31]. In our study, the expression of Bax was increased in breast cancer cells exposed to arantho EO as early as $3 \mathrm{~h}$. These data were consistent with the expression of proteins involved in the intrinsic pathway, and it was expected that the expression of $\mathrm{Bcl}-2$ decreased in the treated cancer cells. Therefore, the results are consistent with other EOs that downregulate $\mathrm{Bcl}-2$ protein expression in different cancer cells to induce apoptosis as a relevant strategy to control cancer development and progression [30]. These observations suggest that $\mathrm{EO}$ is an interesting natural antitumoral candidate for the treatment of cancer. We propose that EO activates the Bax protein, which permeabilizes the outer membrane of mitochondria. This generates large pores that allow the release of cytochrome $\mathrm{c}$ and activate caspase 9 and caspase 3, resulting in cell death.

The cytotoxic activities of natural products, such as EOs, are mainly attributed to the presence of different bioactive compounds, including terpenes, terpenoids, alkanes, and aromatic components [32]. Interestingly, phytochemical analysis of the $D$. bicolor EO showed the presence of different compounds, particularly hydrocarbons and terpenes. 
This result is consistent with the consensus of the chemical composition of EOs, indicating that the three main groups of compounds are terpenes and terpenoids, aromatics (phenolic) and aliphatics [6]. However, 1-5-cyclooc tadiene,3-(methyl-2)propenyl and 1-(3-methyl-cyclopent2-enyl-cyclohexene, two hydrocarbons that were major compounds identified in D. bicolor EO, may be responsible for the cytotoxic activity of this EO towards the MDA-MB-231 breast cancer cells, although nothing is known of its antitumoral activity. Nevertheless, other constituents of EO may contribute to the cytotoxicity. EOs isolated from antitumoral plants of the Rutaceae family of the genus Citrus (C. aurantium, C. limon and C. reticulata) possess a highly different chemical composition compared to $D$. bicolor, which may be due to the difference in their genetic profile and environmental conditions [10]. Moreover, several of the metabolites identified were isolated in other studies and demonstrated cytotoxic and antitumoral activities. One of the three major compounds identified in D. bicolor EO is $\alpha$-terpineol, which decreased both the viability of the MCF-7 breast cancer cell with an $\mathrm{IC}_{50}$ value of $16.2 \mu \mathrm{M}$ [33] and the expression of NF- $\mathrm{kB}$ [34]. Other important less abundant compounds in $D$. bicolor EO that have been isolated from other medicinal plants and possess antitumoral effect are limonene, $\alpha$ pinene and linalool. $\alpha$-Pinene is a monoterpene that induces apoptosis in SK-OV3, HO-8910, Bel-7402 [21] and C32 cancer cells [35]. Linalool had a cytotoxic effect on melanoma [35], breast cancer cells [36] and hepatocarcinoma cells [37]. Limonene is a monoterpene representative of the Rutaceae family. It inhibits the growth of different cell lines, such as DU-145 prostate [38], carcinoma cells, with an $\mathrm{IC}_{50}$ of $2.8 \mathrm{mM}$. However, limonene, linalool and $\alpha$-pinene previously tested on MDA-MB-231 breast cancer cells were not cytotoxic [39]. These investigations indicate that several metabolites present in arantho EO are cytotoxic to different cancer cell lines; however, it is difficult to attribute the biological activity to the entire EO or to one specific compound because the cytostatic effect of an entire plant on cancer cells is often better than the effect of the particular biological active compounds [7]. In addition, due to the lipophilic nature of EO, volatile compounds appear to accumulate in the cell membrane and increase its permeability, resulting in the leakage of enzymes and metabolites that induces cytotoxic and apoptotic effect in cancer cells [6]; however, is necessary to identify the active compound responsible for the cell death of these breast cancer cells.

\section{Conclusion}

In conclusion, several assays demonstrated an important cytotoxic, selective and apoptotic activity of the EO of $D$. bicolor against the breast cancer cell line MDA-MB-231, Additional in vitro and in vivo studies currently under study will allow us to determine the sensitivity of other cell lines and the anti-tumoral potential of the essential oil from arantho (EO).

\section{Additional file}

Additional file 1: MTT assays of the different extracts of $D$. bicolor on MDA-MB-231 breast cancer cell line. The graphics represent the MTT assays of the different extracts (aqueous, ethanolic, acetonic and hexanic) of $D$. bicolor on breast cancer cells MDA-MB-231. The ethanolic, acetonic and hexanic extracts demonstrated a cytotoxic effect in a doses and time dependent manner, obtaining $I C_{50}$ values of $128.20 \pm 2.035,203.2 \pm 2.3$ and $450.7 \pm 2.657 \mu \mathrm{g} / \mathrm{mL}$, respectively. However, the aqueous extract didn't showed any cytotoxic activity at any concentration or time. The experiments were performed at least in triplicate and the values are reported as mean $\pm \mathrm{SE},{ }^{*} P<0.05$ as compared to control cells (medium alone). Significance was analyzed using One-way ANOVA followed by Tukey test. (PDF $270 \mathrm{~kb}$ )

\section{Abbreviations}

DMEM, Dulbecco's Modified Eagle Medium; DMSO, dimethylsulfoxide; EO, essential oil; GC-MS, gas chromatography-mass spectrometry; H\&E, hematoxylin and eosin; Kl, Kovats Retention Index; MTT, 3-(4, 5- dimethylthiazol-2-yl)-2, 5diphenyl tetrazolium bromide; PCNA, proliferating cell nuclear antigen; TUNEL, terminal deoxynucleotidyl transferase-mediated dUTP nick end labeling.

\section{Acknowledgements}

This work was supported by Consejo Nacional de Ciencia y Tecnología (CONACYT) Grant 114028 (Fondo de Investigación en Salud) and by the Instituto Politécnico Nacional Grants SIP 20113658, SIP 20120468 and SIP 20140313. We thank Dr. María de Jesús Perea and Ing. Alberto Peña of the Microscopy Laboratory at the Centro de Nanociencias y Micro y Nanotecnología del IPN for technical assistance. We also thank Dr. Edith Cortés of the Universidad Autónoma Metropolitana, Iztapalapa.

\section{Funding}

This work was supported by Consejo Nacional de Ciencia y Tecnología (CONACYT) Grant 114028 (Fondo de Investigación en Salud) and by the Instituto Politécnico Nacional Grants SIP 20113658, SIP 20120468 and SIP 20140313

\section{Availability of data and materials}

All data and materials are contained and described within the manuscript.

\section{Authors' contributions}

CCEG carried out most of the experiments, contributed to the data interpretation and wrote the initial draft of the manuscript. AAC contributed to the experimental design and Western blot assays. DGPI contributed to data interpretation and the final editing of the manuscript., ESMM and JML

contributed to preparation of essential oil and to its chemical composition by GC-MS. NPH participated in the project design and to the data interpretation. MCGG contributed to the conception and design of the entire study, funding, data interpretation and the final editing of the manuscript. All authors read and approved the final manuscript.

\section{Competing interests}

The authors declare that they have no competing interests.

\section{Consent for publication}

Not applicable.

Ethics approval and consent to participate

Not applicable.

\section{Author details}

${ }^{1}$ Programa de Doctorado en Biotecnología, Escuela Nacional de Medicina y Homeopatía, Instituto Politécnico Nacional, Guillermo Massieu Helguera No. 239, Fracc. La Escalera, Ticomán, Delg. Gustavo A. Madero, Mexico C.P. 07320, D. F., Mexico. ${ }^{2}$ Departamento de Ciencias Químico Biológicas, Instituto de 
Ciencias Biomédicas, Universidad Autónoma de Ciudad Juárez, Anillo Envolvente Pronaf y Estocolmo s/n, C.P. 32310 Cd. Juárez, Chih, Mexico. ${ }^{3}$ Centro de Investigación en Biotecnología Aplicada, Instituto Politécnico Nacional, Tepetitla de Lardizabal, Tlaxcala, Doctorado en Biotecnología, Red de Investigación en Biotecnología IPN, México, Mexico. ${ }^{4}$ Centro de Investigación en Ciencia Aplicada y Tecnología Avanzada, Unidad Legaria, Instituto Politécnico Nacional, Calzada Legaria No. 694 Col. Irrigación, Delg. Miguel Hidalgo, Mexico C.P. 11500, D.F., Mexico.

\section{Received: 28 August 2015 Accepted: 18 May 2016}

\section{Published online: 05 August 2016}

\section{References}

1. Ferlay J, Soerjomataram I, Ervik M, Dikshit R, Eser S, Mathers C, Rebelo M, Parkin DM, Forman D, Bray F. Cancer incidence and mortality Worldwide: sources, methods and major patterns in GLOBOCAN 2012. Int J Cancer. 2015;136:E359-86. doi:10.1002/ijc.29210.

2. Pandey G, Madhuri S. Medicinal plants: better remedy for neoplasm. Indian Drugs. 2006:43:869-74.

3. Kaur R, Singh J, Singh G, Kaur H. Anticancer plants: a review. J Nat Prod Plant Resour. 2011;1(4):131-6. http://scholarsresearchlibrary.com/JNPPR-vol1iss4/JNPPR-2011-1-4-131-136.pdf. Accessed 20 Jan 2015.

4. Agarwal N, Majee C, Chakraborthy GS. Natural herbs as anticancer drugs. Int J PharmTech Res. 2012;4(3):1142-53. http://www.sphinxsai.com/2012/july_ sept12/Pharm/pdfpharm/PT=33\%281142-1153\%29\%20JS\%2012.pdf. Accessed 21 Jan 2015.

5. Prema R, Sathish Sekar D, Chandra Sekhar KB. Review on: herbs as anticancer agents. Int J Pharma \& Ind Res. 2011;1(2):105-8.

6. Bayala B, Bassole IH, Scifo R, Gnoula C, Morel L, Lobaccaro JM, et al. Anticancer activity of essential oils and their chemical components-a review. Am J Cancer Res. 2014;4(6):591-607.

7. Bakkali F, Averbeck S, Averbeck D, Idaomar M. Biological effects of essential oils-a review. Food Chem Toxicol. 2008:46:446-75.

8. Edris AE. Pharmaceutical and therapeutic potentials of essential oils and their individual volatile constituents: a review. Phytothe Res. 2007;21(4):308-23.

9. Smith N, Mori A, Henderson DW, Stevenson DW, Heald SV. Flowering Plants of the Neotropics. New Jersey: Princeton University Press; 2004. p. 333-5.

10. Misharina TA, Samusenko AL. Antioxidant properties of essential oils from lemon, grapefruit, coriander, clove, and their mixtures. Appl Biochem Microbiol. 2008;45(4):438-42.

11. Odeh F, Rahmo A, Alnory SA, Chaty EM. The cytotoxic effect of essential oils Citrus aurantium peels on human colorectal carcinoma cell line (Lim1863). J Microbiol Biotechnol Food Sci. 2012;1(6):1476-87.

12. Berliocchi L, Ciociaro A, Russo R, Cassiano MG, Blandini F, Rotiroti D, et al. Toxic profile of bergamot essential oil on survival and proliferation of $\mathrm{SH}$ SY5Y neuroblastoma cells. Food Chem Toxicol. 2011:49:2780-92.

13. Cárdenas ON, Pérez GS, Zavala SM, Aguirre RJ, Pérez GC. Actividad antifúngica de seis plantas sobre Aspergillus flavus. Revista Mexicana de Ciencias Farmacéuticas. 2005;36(03):21-6.

14. García-Argáez AN, Ramírez Apan TO, Parra Delgado H, Velázquez G, Martínez-Vázquez M. Anti-inflammatory activity of coumarins from Decatropis bicolor on TPA ear mice model. Planta Med. 2000;66(3):279-81.

15. Sánchez GA, Granados SD, Simón NR. Uso medicinal de las plantas por los otomíes del municipio de Nicolás Flores, Hidalgo. México Revista Chapingo Serie Horticultura. 2008;14(3):271-9.

16. Villavicencio NM, Perez EB, Ramírez A. Plantas útiles del Estado de Hidalgo II. Pachuca, Hidalgo: F. Edit. UAEH; 2002. https://books.google.com.mx/books? $\mathrm{id}=$ WXZX5JXDtLOC\&pg=PA13\&lpg=PA13\&dq=plantas+utiles+del+estado+de +hidalgo\&source=bl\&ots=EsP5d-K6sb\&sig =JIKNnWKwZfkSnuda2EKiHsJr80U

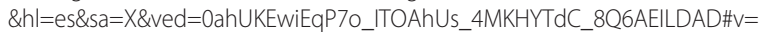
onepage\&q=plantas\%20utiles\%20del\%20estado\%20de\%20hidalgo\&f=false.

17. Pérez EB, Villavicencio NM. Listado de plantas medicinales del Estado de Hidalgo. Pachuca: Universidad Autónoma del Estado de Hidalgo; 1995. p. 45.

18. Cortés CJ. Actividad biológica de extractos de plantas usadas para el tratamiento del cáncer e infecciones en Tepatepec, Hidalgo. 2005. http://www. uaeh.edu.mx/docencia/Tesis/icbi/licenciatura/documentos/Actividad\%20 biologica\%20de\%200extractos.pdf.

19. Calvo-Gómez O, Morales-López J, López M. Solid-phase microextraction-gas chromatographic-mass spectrometric analysis of garlic oil obtained by hydrodistillation. J Chromatogr A. 2004;1036(1):91-3.
20. Mosmann T. Rapid colorimetric assay for cellular growth and survival: application to proliferation and cytotoxicity assay. J Immunol Meth. 1983;65:55-63.

21. Wang W, Li N, Luo M, Zu Y, Efferth T. Antibacterial activity and anticancer activity of Rosmarinus officinalis L. essential oil compared to that of its main components. Molecules. 2012;17(3):2704-13.

22. Atti-Santos AC, Rossato M, Serafini LA, Cassel E, Moyna P. Extraction of essential oils from lime (citrus latifolia Tanaka) by hydrodistillation and supercritical carbon dioxide. Braz Arch Biol Technol. 2005;48(1):155-60.

23. Macías VE, Coy BE, Cuca SL. Preliminary phytochemical analysis and antioxidant, antiinflammatory and antiproliferative activities of the bark ethanol extracts of Zanthoxylum fagara (L.) Sarg. (Rutaceae). Rev Cubana Plant Med. 2011;16(1):43-53.

24. Fadlalla K, Watson A, Yehualaeshet T, Turner T, Smuel T. Ruta graveolens extract induces DNA damage pathways and blocks Akt activation to inhibit cancer cell proliferation and survival. Anticancer Res. 2011;31:233-41.

25. Starmans DAJ, Nijhuis HH. Extraction of secondary metabolites from plant material: a review. Trends Food Sci Techol. 1996;7:191-7.

26. Newman DJ, Cragg GM. Natural products as sources of new drugs over the last 25 years. J Nat Prod. 2007;70(3):461-77.

27. Charafe-Jauffret E, Ginestier C, Monville F, Finetti P, Adélä̈de J, Cervera N, et al. Gene expression profiling of breast cell lines identifies potential new basal markers. Oncogene. 2006;25(15):2273-84.

28. Vermeulen K, Van Bockstaele DR, Berneman ZN. Apoptosis: mechanisms and relevance in cancer. Ann Hematol. 2005;84:627-39.

29. Koff JL, Ramachandiran S, Bernal-Mizrachi L. A time to kill: targeting apoptosis in cancer. Int J Mol Sci. 2015:16:2942-55.

30. Gautam N, Mantha AK, Mittal S. Essential oils and their constituents as anticancer agents: a mechanistic view. BioMed Res Int. 2014;2014:1-23. http://dx.doi.org/10.1155/2014/154106. Accessed 30 Jan 2015.

31. Marzo I, Naval J. BCl-2 family members as molecular targets in cancer therapy. Biochem Pharmacol. 2008;76:939-46.

32. Hamid AA, Aiyelaagbe OO, Usman LA. Essential oils: its medicinal and pharmacological uses. Int J Current Res. 2011;3(2):086-98. http://www. journalcra.com/sites/default/files/Download\%20406.pdf. Accessed 01 Mar 2015

33. Bicas JL, Neri-Numa IA, Ruiz AL, De Carvalho JE, Pastore GM. Evaluation of the antioxidant and antiproliferative potential of bioflavors. Food Chem Toxicol. 2011:49:1610-5.

34. Hassan SB, Gali-Muhtasib H, Göransson H, Larsson R. Alpha terpineol: a potential anticancer agent which acts through suppressing NF-kB signalling. Anticancer Res. 2010;30(6):1911-9. http://ar.iiarjournals.org/content/30/6/ 1911.long. Accessed 01 Mar 2015.

35. Loizzo MR, Tundis R, Menichini F, Saab AM, Statti GA, Menichini F. Antiproliferative effects of essential oils and their major constituents in human renal adenocarcinoma and amelanotic melanoma cells. Cell Prolif. 2008;41:1002-12.

36. Ravizza R, Gariboldi MB, Molteni R, Monti E. Linalool, a plant-derived monoterpene alcohol, reverses doxorubicin resistance in human breast adenocarcinoma cells. Oncol Rep. 2008;20(3):625-30. http://dx.doi.org/10. 3892/or_00000051. Accessed 10 Mar 2015.

37. Usta J, Kreydiyyeh S, Knio K, Barnabe P, Bou-Moughlabay Y, Dagher S. Linalool decreases HepG2 viability by inhibiting mitochondrial complexes I and II, increasing reactive oxygen species and decreasing ATP and GSH levels. Chem Biol Interact. 2009;180(1):39-46.

38. Rabi T, Bishayee A. d-Limonene sensitizes docetaxel-induced cytotoxicity in human prostate cancer cells: generation of reactive oxygen species and induction of apoptosis. J Carcinog. 2009;8:9. http://doi.org/10.4103/14773163.51368. Accessed 10 Mar 2015.

39. Palazzo MC, Agius BR, Wright BS, Haber WA, Moriarity DM, Setzer WN. Chemical compositions and cytotoxic activities of leaf essential oils of four lauraceae tree species from Monteverde, Costa Rica. Rec Nat Prod. 2009;3(1):32-7. 